\title{
Polyphasic identification of Bacillus and Brevibacillus strains from clinical, dairy and industrial specimens and proposal of Brevibacillus invocatus sp. nov.
}

\footnotetext{
${ }^{1}$ School of Biological and Biomedical Sciences, Glasgow Caledonian University, Cowcaddens Road, Glasgow G4 OBA, UK

${ }^{2}$ Laboratorium voor Microbiologie, Universiteit Gent, K. L. Ledeganckstraat 35, B-9000 Gent, Belgium

${ }^{3}$ CCUG, Culture Collection, University of Göteborg, Dept of Clinical Bacteriology, Guldhedsgatan 10, S-413 46 Göteborg, Sweden

${ }^{4}$ Department of Medical Microbiology, Lund University, Sölvegatan 23, S-223 62 Lund, Sweden

${ }^{5}$ Regional Centre for Communicable Disease Control, University Hospital MAS, Malmö, Sweden
}

\author{
N. A. Logan, ${ }^{1}$ G. Forsyth, ${ }^{1}$ L. Lebbe, ${ }^{2}$ J. Goris, ${ }^{2}$ M. Heyndrickx, ${ }^{2} \dagger$ \\ A. Balcaen, ${ }^{2}$ A. Verhelst, ${ }^{2}$ E. Falsen, ${ }^{3}$ Å. Ljungh, ${ }^{4}$ H. B. Hansson ${ }^{5}$ \\ and P. De Vos $^{2}$

\begin{abstract}
Author for correspondence: N. A. Logan. Tel: +44 141331 3207. Fax: +44 1413313208 e-mail:n.a.logan@gcal.ac.uk
\end{abstract}

\begin{abstract}
Thirty-three clinical, dairy and industrial isolates of aerobic endospore-forming bacteria which were unreactive in routine identification tests were characterized genotypically by using amplified rDNA restriction analysis (ARDRA), 16S rDNA sequencing and DNA-DNA reassociation, and phenotypically by using fatty acid methyl ester (FAME) analysis, SDS-PAGE of whole-cell proteins, API Biotype 100 assimilation tests and 16 other routine phenotypic tests. Three isolates were identified as strains of Bacillus badius, 12 as Brevibacillus agri, including 3 strains associated with an outbreak of waterborne illness, 4 as Brevibacillus centrosporus and 2 as Brevibacillus parabrevis; 12 strains contaminating an antibiotic production plant were recognized as members of a new species, for which the name Brevibacillus invocatus is proposed, with the type strain LMG $18962^{\top}\left(=\right.$ B2156 $^{\top}=$ CIP $_{106911^{\top}}=\mathrm{NCIMB}^{\circ}$ 13772').
\end{abstract}

Keywords: Aneurinibacillus, Bacillus badius, Brevibacillus, Brevibacillus invocatus, Brevibacillus agri waterborne illness

\section{INTRODUCTION}

Following DNA relatedness and chemotaxonomic studies, some 'Bacillus brevis' strains were assigned to the new species 'Bacillus agri' and 'Bacillus centrosporus' (Nakamura, 1993), 'Bacillus migulanus', 'Bacillus choshinensis', 'Bacillus parabrevis' and 'Bacillus galactophilus' (Tagaki et al., 1993), and 'Bacillus reuszeri', 'Bacillus formosus' and 'Bacillus borstelensis' (Shida et al., 1995), but 'Bacillus galactophilus' was later recognized to be a synonym of 'Bacillus agri'

\footnotetext{
†Present address: Government Dairy Research Station, Brusselsesteenweg 370, B-9090 Melle, Belgium.

Abbreviations: ARDRA, amplified rDNA restriction analysis; FAME, fatty acid methyl ester.

The EMBL accession number for the 16S rRNA gene sequence of Brevibacillus invocatus LMG $18962^{\top}$ is AF378232. The accession numbers for the other 16S rRNA gene sequences are: Brevibacillus agri LMG 18172, AF378233; Brevibacillus borstelensis LMG 15536, AF378230; Brevibacillus formosus LMG 16101, AF378234; Brevibacillus invocatus LMG 18167, AF378231.
}

(Shida et al., 1994b). Also, 'Bacillus aneurinolyticus' was revived (Shida et al., 1994a); this organism was already known to resemble 'Bacillus brevis' and related taxa (Claus \& Berkeley, 1986), and Bacillus badius phenotypically, but that is to say most such strains are unreactive in many of the biochemical tests upon which the two main identification schemes are based and identifications rely too heavily on negative test results.

Studies on the $16 \mathrm{~S}$ rDNA sequences of the type strains of 'Bacillus brevis' and 'Bacillus aneurinolyticus' suggested that the latter represented a distinct evolutionary line close to that of 'Bacillus brevis' (Ash et al., 1991) or that it diverged early from the 'Bacillus brevis' line (Farrow et al., 1992, 1994). On the basis of a $16 \mathrm{~S}$ rDNA gene sequence analysis of the type strains only, Shida et al. (1996) proposed two new genera to accommodate the above-mentioned and allied species: Aneurinibacillus contains Aneurinibacillus aneurinilyticus and Aneurinibacillus migulanus, while Brevibacillus contains Brevibacillus brevis and the seven species derived from it, Brevibacillus laterosporus and the 
Table 1. Designations and sources of clinical, dairy and pharmaceutical isolates, Aneurinibacillus, Bacillus and Brevibacillus reference strains used and an overview of the different characterization methods applied to them

The following reference strains were studied by ARDRA only: Bacillus amyloliquefaciens LMG $9814^{\mathrm{T}}$, Bacillus azotoformans LMG 9581 ${ }^{\mathrm{T}}$, Bacillus cereus LMG 6923 , Bacillus circulans LMG 13261 ${ }^{\mathrm{T}}$, Bacillus firmus LMG 7125 ${ }^{\mathrm{T}}$, Bacillus licheniformis LMG $6933^{\mathrm{T}}$, Bacillus megaterium LMG $7127^{\mathrm{T}}$, Bacillus simplex LMG $11160^{\mathrm{T}}$, Bacillus subtilis LMG $7135^{\mathrm{T}}$, Bacillus thuringiensis LMG $7138^{\mathrm{T}}$. Abbreviations: ÅL, Å. Ljungh, Department of Medical Microbiology, Lund University, Sweden; ATCC, American Type Culture Collection, Manassas, VA, USA; B, N. A. Logan Bacillus Collection, Glasgow Caledonian University, Glasgow, UK; C, antibiotic fermenter contaminant strain designation; CCUG, Culture Collection, University of Göteborg, Göteborg, Sweden; CIP, Institut Pasteur, Paris, France; DSM, Deutsche Sammlung von Mikroorganismen und Zellculturen, Braunschweig, Germany; G, Gibson, T. Gibson Collection, held at Glasgow Caledonian University; Goodfellow, M. Goodfellow, University of Newcastle, Newcastle upon Tyne, UK; Gordon, R. E. Gordon, Rutgers University, New Brunswick, USA; IFO, Institute of Fermentation, Osaka, Japan; LMG, Laboratorium voor Microbiologie, Universiteit Gent, Gent, Belgium; NCA, National Canners Association, Washington, DC, USA; NCIMB, National Collection of Industrial and Marine Bacteria, Aberdeen, UK; NCTC, National Collection of Type Cultures, Central Public Health Laboratory, London, UK; NRRL, Northern Regional Research Laboratory Collection, Peoria, IL, USA; NRS, N. R. Smith Collection, now held at NRRL; R-, research collection, Laboratorium voor Microbiologie, Universiteit Gent, Gent, Belgium; Wellcome, Wellcome Collection of Micro-organisms, Beckenham, Kent, UK.

\begin{tabular}{|c|c|c|c|c|}
\hline Name as received & $\begin{array}{l}\text { Present taxonomic } \\
\text { status (if changed) }\end{array}$ & Study no. & $\begin{array}{c}\text { Other } \\
\text { designations }\end{array}$ & Source \\
\hline Aneurinibacillus aneurinilyticus & & LMG $15531^{\mathrm{T}}$ & $\mathrm{B} 0205^{\mathrm{T}}$, ATCC $12856^{\mathrm{T}}$ & Gordon \\
\hline Aneurinibacillus aneurinilyticus & & LMG 15533 & B0207, NRRL NRS-1449, Li strain & Gordon \\
\hline Aneurinibacillus migulanus & & LMG $15427^{\mathrm{T}}$ & B0270 ${ }^{\mathrm{T}}$, NCTC $7096^{\mathrm{T}}$, ATCC $9999^{\mathrm{T}}$ & NCTC \\
\hline Aneurinibacillus migulanus & & LMG 16098 & B4036, NRRL NRS-606 & NRRL \\
\hline Aneurinibacillus thermoaerophilus & & LMG $17165^{\mathrm{T} *}+\|$ & DSM $10154^{\mathrm{T}}$ & DSM \\
\hline Aneurinibacillus thermoaerophilus & & LMG $17166 * \ddagger \|$ & DSM 10155 & DSM \\
\hline Bacillus badius & & LMG $7122^{\mathrm{T}}$ & $\mathrm{B} 1903^{\mathrm{T}}, \mathrm{B} 0180^{\mathrm{T}}$ DSM $23^{\mathrm{T}}$ & DSM \\
\hline Bacillus badius & & LMG 12332 & B0201, NRS 1407 & Gordon \\
\hline Bacillus sp. & Bacillus badius & LMG 18004 & B2083 & Gelatin processing plant \\
\hline Bacillus sp. & Bacillus badius & LMG 18005 & B2084 & Gelatin processing plant \\
\hline Bacillus sp. & Bacillus badius & LMG 18006 & B2085 & Gelatin processing plant \\
\hline Bacillus sp. & Brevibacillus agri & LMG 18007 & B2086 & Gelatin processing plant \\
\hline Bacillus sp. & Brevibacillus agri & LMG 18008 & B2378 & Gelatin processing plant \\
\hline Bacillus sp. & Brevibacillus agri & LMG 18071 & B1577, ÅL 1 & Water-borne illness \\
\hline Bacillus sp. & Brevibacillus agri & LMG 18072 & B1578, ÅL 2 & Water-borne illness \\
\hline Bacillus sp. & Brevibacillus agri & LMG 18073 & B1579, ̊L 3 & Water-borne illness \\
\hline Bacillus sp. & Brevibacillus agri & LMG $18960^{*}$ & $\mathrm{~B} 2142, \mathrm{C} 2392$ & Antibiotic fermenter \\
\hline Bacillus sp. & Brevibacillus agri & LMG 18965 & B2143, C2543 & Antibiotic fermenter \\
\hline Bacillus sp. & Brevibacillus agri & LMG 18162 & B2159, C3793 & Antibiotic fermenter \\
\hline Bacillus sp. & Brevibacillus agri & LMG 18171 & B2144, C2714 & Antibiotic fermenter \\
\hline Bacillus sp. & Brevibacillus agri & LMG $18172 \dagger$ & B2146, C2922 & Antibiotic fermenter \\
\hline Bacillus sp. & Brevibacillus invocatus & LMG $18161^{*}$ & B2153, C3739 & Antibiotic fermenter \\
\hline Bacillus sp. & Brevibacillus invocatus & LMG 18164 & $\mathrm{~B} 2150, \mathrm{C} 3735$ & Antibiotic fermenter \\
\hline Bacillus sp. & Brevibacillus invocatus & LMG 18165 & B2141, C0006 & Antibiotic fermenter \\
\hline Bacillus sp. & Brevibacillus invocatus & LMG 18166 & B2163, C4309 & Antibiotic fermenter \\
\hline Bacillus sp. & Brevibacillus invocatus & LMG $18167 \dagger$ & $\mathrm{B} 2161, \mathrm{C} 3950$ & Antibiotic fermenter \\
\hline Bacillus sp. & Brevibacillus invocatus & LMG 18169 & $\mathrm{~B} 2158, \mathrm{C} 3776$ & Antibiotic fermenter \\
\hline Bacillus sp. & Brevibacillus invocatus & LMG 18170 & B2162, C3994 & Antibiotic fermenter \\
\hline Bacillus sp. & Brevibacillus invocatus & LMG $18959 \ddagger$ & $\mathrm{B} 2151, \mathrm{C} 3736$ & Antibiotic fermenter \\
\hline Bacillus sp. & Brevibacillus invocatus & LMG $18961 \S$ & B2164, C4014 & Antibiotic fermenter \\
\hline Bacillus sp. & Brevibacillus invocatus & LMG $18962^{\mathrm{T}} \dagger$ & B2156 ${ }^{\mathrm{T}}$, NCIMB $13772^{\mathrm{T}}$, CIP $106911^{\mathrm{T}}, \mathrm{C} 3774^{\mathrm{T}}$ & Antibiotic fermenter \\
\hline Bacillus sp. & Brevibacillus invocatus & LMG 18963 & B2152, C 3738 & Antibiotic fermenter \\
\hline Bacillus sp. & Brevibacillus invocatus & LMG 18966 & B2155, C3749 & Antibiotic fermenter \\
\hline Brevibacillus agri & Brevibacillus parabrevis & LMG 15101 & B4000, CCUG 27608 & Blood isolate \\
\hline Brevibacillus brevis & Brevibacillus parabrevis & LMG 15104 & B1915, CCUG 29760 & Breast abscess \\
\hline Brevibacillus brevis & Brevibacillus parabrevis & LMG 15426 & B0118, Gibson 539 & Gibson \\
\hline Brevibacillus brevis & Brevibacillus agri & LMG 15431 & B0629, Wellcome 2934 & Goodfellow \\
\hline Brevibacillus brevis & Brevibacillus borstelensis & LMG 15536 & B0627, Wellcome 2918 & Goodfellow \\
\hline Brevibacillus brevis & Brevibacillus agri & LMG 19651* & B2097, R-2139 & Sterilized milk \\
\hline Brevibacillus brevis & Brevibacillus agri & LMG $19652 *$ & B2098, R-2140 & Sterilized milk \\
\hline Brevibacillus laterosporus & Brevibacillus centrosporus & LMG 15107 & B4018, CCUG 28806 & Human blood \\
\hline Brevibacillus laterosporus & Brevibacillus centrosporus & LMG 15108 & B4019, CCUG 28967 & Human blood \\
\hline Brevibacillus laterosporus & Brevibacillus sp. & LMG 15111 & B4022, CCUG 29854 & Industrial isolate \\
\hline Brevibacillus laterosporus & Brevibacillus centrosporus & LMG 15112 & B4023, CCUG 29969 & Human blood \\
\hline Brevibacillus laterosporus & Brevibacillus centrosporus & LMG 15113 & B4024, CCUG 31314 & Bronchio-alveolar lavage \\
\hline Brevibacillus agri & & LMG $15103^{\mathrm{T}}$ & B $4008^{\mathrm{T}}$, NRRL NRS- $1219^{\mathrm{T}}$, CCUG $31345^{\mathrm{T}}$ & CCUG \\
\hline Brevibacillus agri & & LMG 15592 & B4001, NRRL B-1157 & NRRL, clinical isolate \\
\hline Brevibacillus agri & & LMG 15593 & B4003, NRRL B-1158 & NRRL, clinical isolate \\
\hline Brevibacillus agri & & LMG 15594 & B4004, NRRL NRS- 873 , 'Bacillus hollandicus' & NRRL \\
\hline Brevibacillus agri & & LMG 15595 & B4005, NRRL NRS- 874, 'Bacillus hollandicus' & NRRL \\
\hline Brevibacillus agri & & LMG 15596 & B4006, NRRL NRS-1002, 'Bacillus ventricosus' & NRRL \\
\hline Brevibacillus agri & & LMG 15597 & B4007, NRRL NRS-1028 & NRRL \\
\hline Brevibacillus agri & & LMG 16099 & B4025, NRRL NRS-616, & NRRL \\
\hline Brevibacillus borstelensis & & LMG $16009^{\mathrm{T}}$ & B $4029^{\mathrm{T}}$, NRRL NRS-818 ${ }^{\mathrm{T}}$, IFO15714 ${ }^{\mathrm{T}}$ & IFO \\
\hline Brevibacillus borstelensis & & LMG 15429 & B0626, Wellcome 2904 & Goodfellow \\
\hline
\end{tabular}


Table 1 (cont.)

\begin{tabular}{|c|c|c|c|c|}
\hline Name as received & $\begin{array}{l}\text { Present taxonomic } \\
\text { status (if changed) }\end{array}$ & Study no. & $\begin{array}{c}\text { Other } \\
\text { designations }\end{array}$ & Source \\
\hline Brevibacillus borstelensis & & LMG 15599 & B4009, NRRL NRS-1373, 'Bacillus agri' & NRRL, hot spring \\
\hline Brevibacillus borstelensis & & LMG $16103 \ddagger$ & B4030, NRRL NRS-1029b, 'Bacillus schuylkilliensis' & NRRL \\
\hline Brevibacillus borstelensis & & LMG 16208 & B4028, NCIMB 8803, Knaysi 80 & NCIMB \\
\hline Brevibacillus brevis & & LMG $16703^{\mathrm{T}}$ & $\mathrm{B} 1881^{\mathrm{T}}$, ATCC $8246^{\mathrm{T}}$ & ATCC \\
\hline Brevibacillus brevis & & LMG $17054 \dagger$ & B2025, ATCC 11031 & ATCC \\
\hline Brevibacillus brevis & & LMG $17055 \ddagger$ & ATCC 35690 & ATCC \\
\hline Brevibacillus centrosporus & & LMG $15106^{\mathrm{T}}$ & B $4016^{\mathrm{T}}$, CCUG $31347^{\mathrm{T}}$, NRS $664^{\mathrm{T}}$ & CCUG \\
\hline Brevibacillus centrosporus & & LMG $15600 \ddagger$ & B4012, NRRL NRS-135, NCA 11773-2 & NRRL, from spinach \\
\hline Brevibacillus centrosporus & & LMG 15601 & B4013, NRRL NRS-136, NCA 11773-8 & NRRL \\
\hline Brevibacillus centrosporus & & LMG 15602 & B4015, NRRL NRS-632, 'Bacillus rarus' & NRRL \\
\hline Brevibacillus centrosporus & & LMG 15604 & B4017, NRRL NRS-925, 'Bacillus pallidus' & NRRL \\
\hline Brevibacillus centrosporus & & LMG 15713 & B4014, NRRL NRS-628 & NRRL \\
\hline Brevibacillus choshinensis & & LMG $15968^{\mathrm{T}}$ & B $4046^{\mathrm{T}}$, ATCC $51359^{\mathrm{T}}$ & ATCC \\
\hline Brevibacillus choshinensis & & LMG 16095* & B4032, NRRL NRS-376 & NRRL, soil \\
\hline Brevibacillus choshinensis & & LMG 16096 & B4033, NRRL NRS-378 & NRRL, soil \\
\hline Brevibacillus choshinensis & & LMG 16097 & B4034, NRRL NRS-380 & NRRL, soil \\
\hline Brevibacillus formosus & & LMG $16010^{\mathrm{T}}$ & B $4039^{\mathrm{T}}$, NRRL NRS- $863^{\mathrm{T}}$ & NRRL \\
\hline Brevibacillus formosus & & LMG 16101 & B4040, NRRL NRS-910 & NRRL \\
\hline Brevibacillus laterosporus & & LMG $16000^{\mathrm{T}}$ & B $4035^{\mathrm{T}}$, DSM $25^{\mathrm{T}}$, ATCC $64^{\mathrm{T}}$, Ford $29^{\mathrm{T}}$ & DSM \\
\hline Brevibacillus laterosporus & & LMG $15109 \ddagger$ & B4020, CCUG 29453, NRRL B-4190 & CCUG \\
\hline Brevibacillus laterosporus & & LMG $15110 \ddagger$ & B4021, CCUG 29454, NRRL B-14295 & CCUG \\
\hline Brevibacillus laterosporus & & LMG $15433 \ddagger$ & B0026, $8 / 1 / 15 / 1$ & Bristol \\
\hline Brevibacillus laterosporus & & LMG 15434 & B0043, 8/1/15/1 colonial variant & Bristol \\
\hline Brevibacillus laterosporus & & LMG 15435 & B 0115, G 308, NCTC 7579 & Gibson \\
\hline Brevibacillus laterosporus & & LMG $15436 \ddagger$ & B0116, G 1066, 'Bacillus orpheus' & Gibson \\
\hline Brevibacillus laterosporus & & LMG $15437 \ddagger$ & B0262 & Laboratory contaminant \\
\hline Brevibacillus laterosporus & & LMG $15439 \ddagger$ & B0309, G 1080, 'Bacillus orpheus' & Gibson \\
\hline Brevibacillus laterosporus & & LMG $15440 \ddagger$ & B0311, G 5, 'Bacillus pyenoticus' & Gibson \\
\hline Brevibacillus laterosporus & & LMG $15441 \ddagger$ & B0616, NRS 682, 'Bacillus orpheus' & Goodfellow \\
\hline Brevibacillus parabrevis & & LMG $15971^{\mathrm{T}}$ & $\mathrm{B} 4047^{\mathrm{T}}$, NRS $605^{\mathrm{T}}$, ATCC $10027^{\mathrm{T}}$ & ATCC \\
\hline Brevibacillus parabrevis & & LMG 15428 & B0271, NCTC 7577, G 108 & Gibson \\
\hline Brevibacillus parabrevis & & LMG 15973 & B4048, ATCC 8185, NRS 751, & ATCC, soil, gramicidin strain \\
\hline Brevibacillus parabrevis & & LMG 16011 & B4037, NRS 779, ATCC 8186, IFO 12333 & IFO \\
\hline Brevibacillus parabrevis & & LMG $16100 *$ & B4038, NRRL NRS-815 & NRRL \\
\hline Brevibacillus reuszeri & & LMG $16012^{\mathrm{T}}$ & B $4042^{\mathrm{T}}$, IFO $15719^{\mathrm{T}}$, NRRL NRS-1206 $6^{\mathrm{T}}$, Reuszer $39^{\mathrm{T}}$ & IFO \\
\hline Brevibacillus reuszeri & & LMG 16105 & B4043, NRRL NRS-1207, Reuszer 723 & NRRL \\
\hline Brevibacillus reuszeri & & LMG 16106* & B4044, NRRL NRS-1208, Reuszer 842 & NRRL \\
\hline Brevibacillus thermoruber & & LMG $16910^{\mathrm{T}} \$ \|$ & $\mathrm{B} 1858^{\mathrm{T}}$, DSM $7064^{\mathrm{T}}$ & DSM \\
\hline
\end{tabular}

* Strain not included in FAME analysis.

$\dagger$ Strain subjected to 16S rDNA sequencing.

+ Strain giving unclear PAGE profile and so not shown in Figs 2 and 3; or in the case of strains LMG 15533, LMG 16100, LMG $16910^{\mathrm{T}}$, LMG 17165 and LMG 17166, not included in analysis.

$\S$ Strain not included in ARDRA.

\| Strain not characterized by tests in API system, other biochemical tests and morphological observations.

thermophile Brevibacillus thermoruber. Heyndrickx et al. (1997) transferred another thermophilic species, 'Bacillus thermoaerophilus', to Aneurinibacillus following a polyphasic taxonomic study.

Thus, strains which might previously have been assigned to 'Bacillus brevis' now represent some 10 mesophilic species in two genera. Their distinctions are based mainly upon DNA relatedness studies, molecular probing and chemotaxonomic analyses of the relatively few available isolates, using databases which are largely restricted to reference laboratories and unsuitable for organisms only occasionally encountered in routine laboratories. Distinction of most Aneurinibacillus and Brevibacillus species is not possible using the currently available Bacillus identification schemes and separation remains difficult even with much wider selections of phenotypic tests (Heyndrickx et al., 1997). Also, another unreactive species, Bacillus badius, may easily be misidentified as a member of these genera. It is unfortunate that the extensive splitting proposed by the various recent taxonomic studies has not revealed characteristic phenotypic profiles which would be of value in the routine laboratory.

Unreactive, aerobic, endospore-forming isolates from an outbreak of water-borne illness, from other clinical specimens, from 'sterilized' milk and from pharmaceutical manufacturing plants have been submitted to our laboratories for identification over the last few years. These referrals reflect the difficulties such organisms present to routine laboratories, where it is important to know that the isolate is neither Bacillus anthracis nor Bacillus cereus, nor yet a member of another species with a record of opportunistic pathogenicity. This prompted us to carry out a polyphasic taxonomic study of unreactive, aerobic endospore- 
formers to identify these organisms, and in so doing we recognized a new species which we propose as Brevibacillus invocatus.

\section{METHODS}

Strains. The designations of the clinical and pharmaceutical isolates and reference strains, their origins and the different methods applied to them are shown in Table 1. Strains LMG 18071-18073 were isolated in connection with an outbreak of water-borne illness in four Swedish towns (total population 84500) in November 1995, following the accidental overload of a purification plant with raw water. Responses to a questionnaire distributed in two affected towns and one unaffected control town revealed that $64-86 \%$ of affected households complained about water odour and taste, and that about $15-17 \%$ of persons in the affected towns reported symptoms of (in order of decreasing frequency) abdominal pain, diarrhoea, myalgia, vomiting and fever. Symptoms appeared in slightly less than $24 \mathrm{~h}$ and most patients recovered in 1-4 days. Strains LMG 18161, 18162, 1816418167, 18169-18172, 18959-18963 and 18965 were contaminants isolated from a pharmaceutical fermenter plant and its antibiotic raw product over a period of several months from 1996 to 1997 . Strains LMG 18004-18008 were isolated from an industrial plant which produces gelatin from animal skin and bone for pharmaceutical capsule manufacture. Strains LMG 19651 and 19652 were isolated from sterilized milk. Strains LMG 15101, 15104, 15107, 15108, 15112 and 15113 were isolated from clinical specimens in a Swedish medical laboratory; their clinical sources are indicated in Table 1. Strains of Aneurinibacillus thermoaerophilus were only analysed by amplified rDNA restriction analysis (ARDRA) in the present study as their high growth temperature $\left(55^{\circ} \mathrm{C}\right)$ requirement made direct phenotypic comparison with the other species untenable; the relationship of this species to the other species of Aneurinibacillus and to Brevibacillus species was discussed by Heyndrickx et al. (1997).

Cultivation and maintenance of strains. Unless otherwise stated, all strains were grown for the different analyses on nutrient agar with $1 \%(\mathrm{w} / \mathrm{v})$ glucose $(\mathrm{pH} \mathrm{7.4)}(\mathrm{NAG})$ at $30{ }^{\circ} \mathrm{C}$ for $24-48 \mathrm{~h}$. The strains were checked for purity by plating and phase-contrast microscopic examination and were maintained both as lyophilized cultures and as sporulated cultures on $\mathrm{NAG}$ slopes containing $5 \mathrm{mg} \mathrm{MnSO}_{4}$. $4 \mathrm{H}_{2} \mathrm{Ol}^{-1}$ (to enhance sporulation). Slopes were incubated for $48 \mathrm{~h}$ or longer until spores could be observed by microscopy, then stored at $4{ }^{\circ} \mathrm{C}$.

DNA preparation. DNA was prepared and stored as described by Logan et al. (2000).

ARDRA. Enzymically amplified $16 \mathrm{~S}$ rDNA was obtained by PCR and analysed by restriction digestion with five restriction enzymes (HaeIII, DpnII, RsaI, BfaI and Tru9I) as described previously (Heyndrickx et al., 1996b). Identification of isolates was attempted by comparing ARDRA profiles with a database of over 1000 authentic strains of aerobic endospore-formers.

DNA base composition. DNA was enzymically degraded into nucleosides as described by Mesbah et al. (1989). The nucleoside mixture obtained was then separated by HPLC using a Waters Symmetry Shield C8 column thermostabilized at $37^{\circ} \mathrm{C}$. The solvent was $0.02 \mathrm{M} \mathrm{NH}_{4} \mathrm{H}_{2} \mathrm{PO}_{4}(\mathrm{pH} 4 \cdot 0$ ) with $1.5 \%(\mathrm{v} / \mathrm{v})$ acetonitrile. Non-methylated $\lambda$ phage DNA (Sigma) was used as the calibration reference.
Percentage DNA-DNA binding. DNA-DNA hybridizations were performed with photobiotin-labelled probes in microplate wells as described by Ezaki et al. (1989), using an HTS7000 Bio Assay Reader (Perkin Elmer) for the fluorescence measurements (excitation filter $360 \mathrm{~nm}$, emission filter $465 \mathrm{~nm}$ ). The optimal renaturation temperature was determined according to the equation of De Ley et al. (1970).

16S rDNA sequencing. This was carried out as described by Logan et al. (2000).

Gas chromatographic analysis of fatty acid methyl esters (FAMEs). Cells were grown and analysed as described by Heyndrickx et al. (1998), using the methods of Vauterin et al. (1991).

SDS-PAGE of whole-cell proteins. Cells were obtained as described by Heyndrickx et al. (1998), the SDS protein extracts prepared and electrophoresed according to Pot et al. (1994) and the data collected and interpreted as described by Vauterin \& Vauterin (1992).

Phenotypic characterization and numerical analysis. Organisms were cultivated and characterized and the results subjected to numerical analysis and expressed as percentage $S_{\mathrm{G}}$, following the methods described by Heyndrickx et al. (1997). Five strains were characterized blind, in duplicate, to give an indication of test error.

\section{RESULTS AND DISCUSSION}

The ARDRA cluster containing the type strain of Brevibacillus agri (Fig. 1) also contained Brevibacillus brevis $\mathrm{LMG} 16703^{\mathrm{T}}$ and so it is evident that this technique was unable to discriminate between these two species. The type strains of Brevibacillus centrosporus, Brevibacillus choshinensis and Brevibacillus formosus, LMG $15106^{\mathrm{T}}, 15968^{\mathrm{T}}$ and $16010^{\mathrm{T}}$, and other authentic strains of these species were also not recovered in separate clusters by ARDRA, and all of these five species appeared as members of what we may refer to as the 'Brevibacillus brevis ARDRA complex', which formed at $88 \%$ similarity. This lack of discrimination between some Brevibacillus species in ARDRA was observed to a lesser extent by Heyndrickx et al. (1997) when the Brevibacillus brevis and Brevibacillus agri strains were not separated in ARDRA, but were separable by PAGE and API and other phenotypic characters; in that study, however, most Brevibacillus species were represented by only two strains. In the present work, some members of the Brevibacillus brevis ARDRA complex were separated by PAGE (Figs 2 and 3), with most strains of Brevibacillus agri being recovered in a distinct cluster, but API and other phenotypic tests were unable to separate all the members of the complex satisfactorily (Fig. 4). However, in the latter analysis the estimated probability of test inconsistency was $4 \%$, indicating that separations of much less than $6-8 \% S_{\mathrm{G}}$ were probably of little significance. In the $16 \mathrm{~S}$ rDNA sequence comparison tree (Fig. 5), most species of the genus Brevibacillus were represented by more than one strain and it can be seen that several of the species were not well separated. This is perhaps not surprising, as such species were delineated primarily upon the basis of DNA related- 
لسسسلسسسلسسسسلسسسلسسسللا
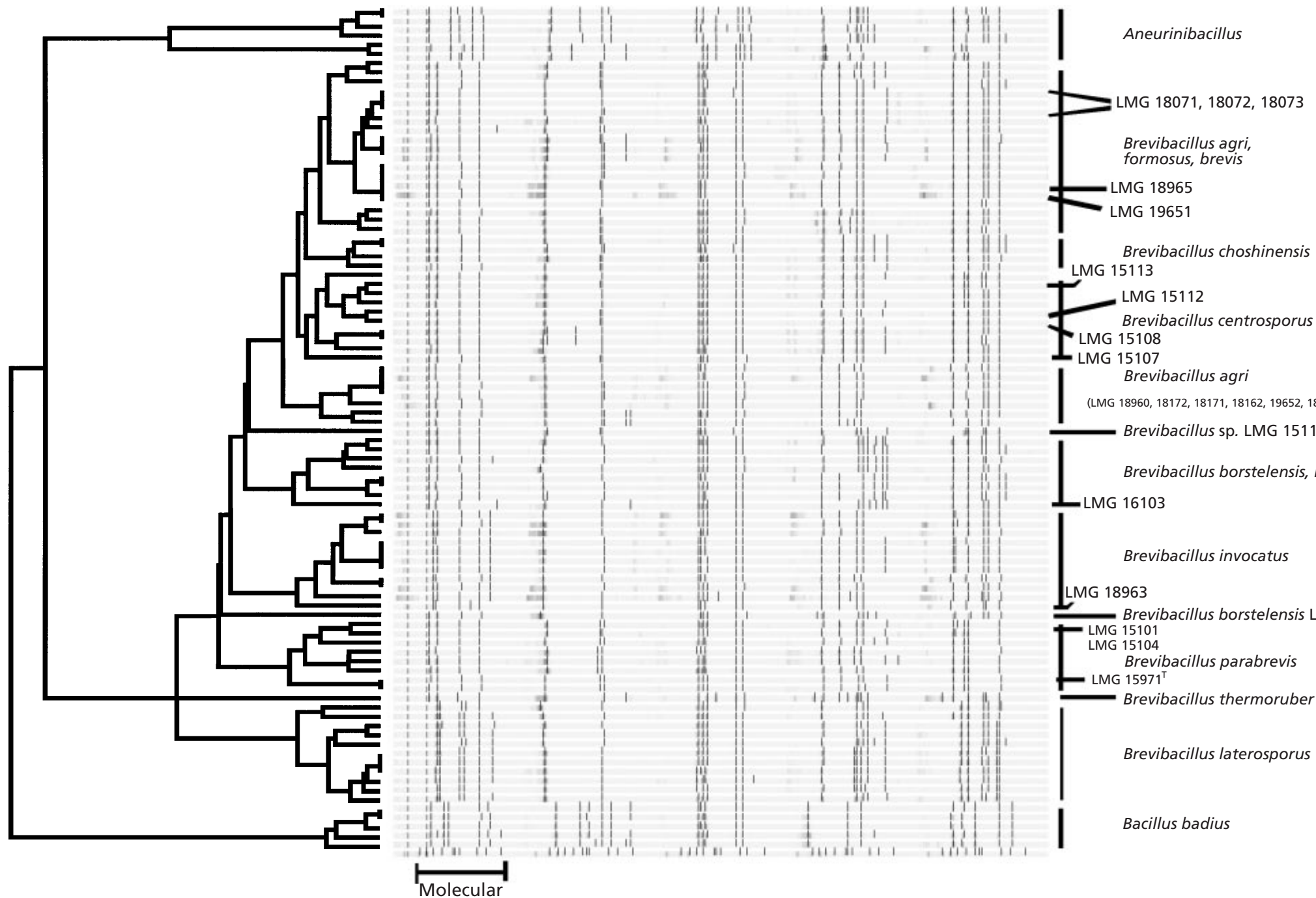

$$
\text { Brevibacillus agri }
$$

(LMG 18960, 18172, 18171, 18162, 19652, 18007, 18008) Brevibacillus sp. LMG 15111

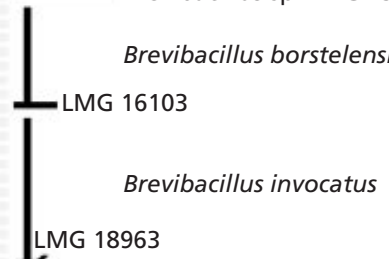

Brevibacillus borstelensis LMG 15536 LMG 15101

Brevibacillus parabrevis

— LMG 15971

Brevibacillus thermoruber

Brevibacillus laterosporus

Bacillus badius

Fig. 1. Dendrogram of UPGMA clustering of correlation coefficients (Dice) of normalized 165 rDNA restriction analysis data (ARDRA) of representatives of Aneurinibacillus migulanus (2 strains), Aneurinibacillus aneurinilyticus (2 strains) and Aneurinibacillus thermoaerophilus (2 strains), and 5 Bacillus badius strains and 81 Brevibacillus strains. For details of strains see Table 1. The molecular mass marker contained, from right to left, 10 bands of $910,659,521,403$, 281, 257, 226, 136, 100 and 63 bp. The marker was prepared as described by Heyndrickx et al. (1996b). 

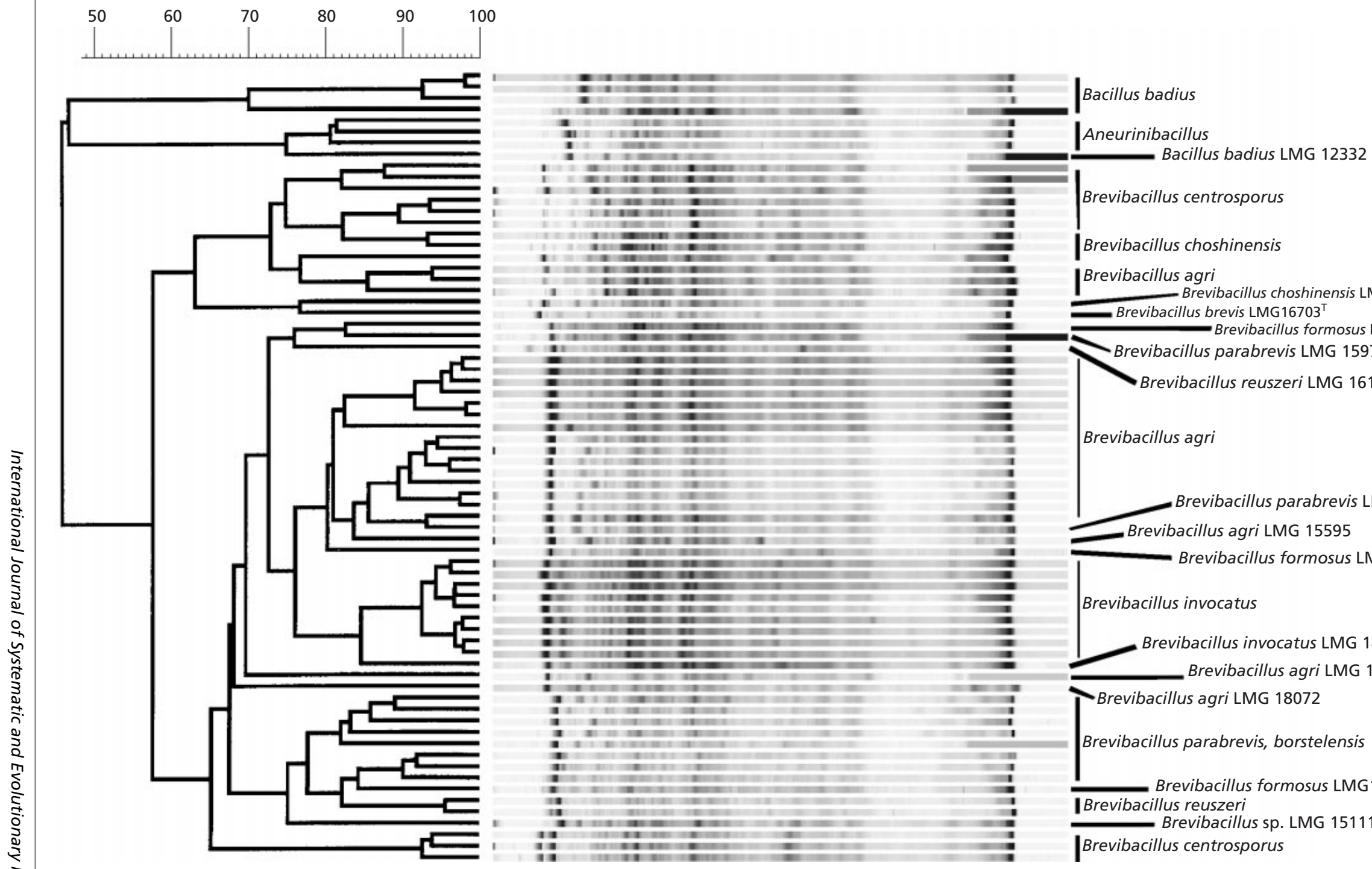

Brevibacillus choshinensis

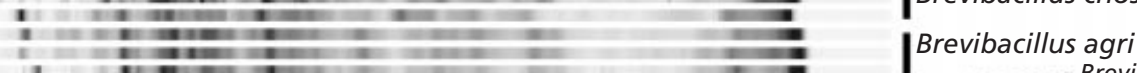

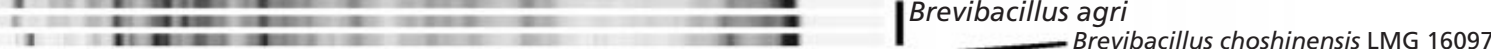
a n a

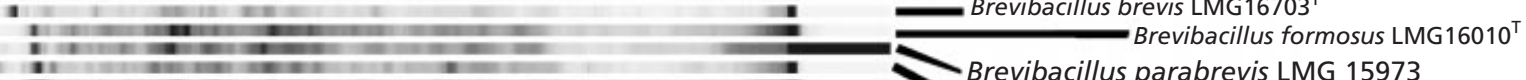
Brevibacillus parabrevis LMG 15973 =Brevibacillus parabrevis LMG 15973$$
\text { . }
$$

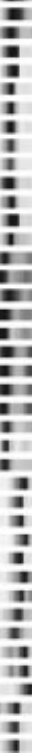
based on UPGMA clustering of the correlation coefficient $(r)$ of total protein profiles. The zone used for clustering analysis was between points 30 and 330 (a complete lane contained 400 points). 
(a)

Similarity (\%)

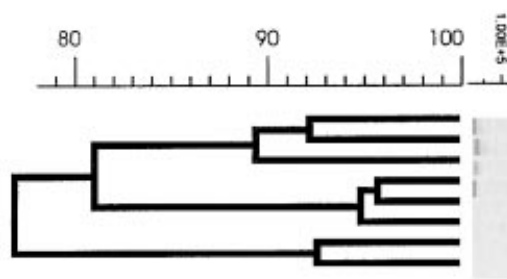

(b)

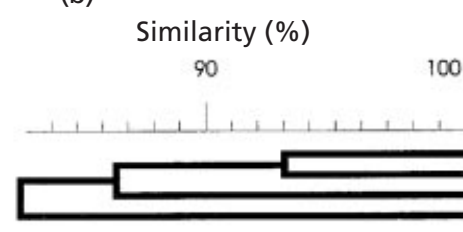

100

(c)
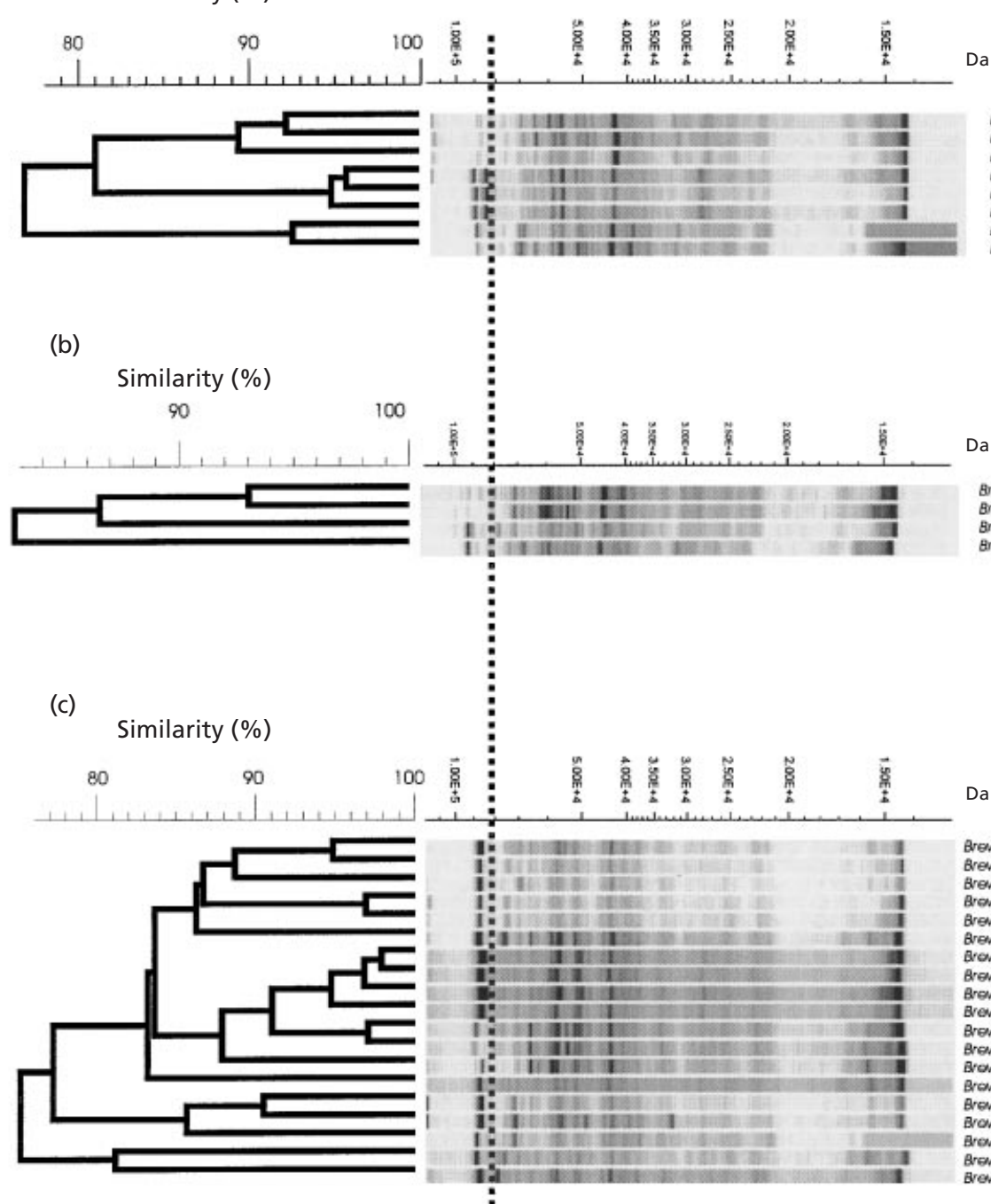

$\mathrm{Da}$

Brovibooillus centro\$porus LMG 15106 T Eromibocomiss controsporus LAG 15002 a vilbocolus cantroporus LMG 15001 Brovilus

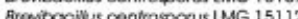
Broviboilus Bremibocilits controporis LMG 1560 Da

Arevibocitus chashinennsis LMG 16095 Brembockinus chashinennsis LMG 16096 Breviboctivus choshinennsis LMG 16097
Brembocthus chashinennsis LMG 15968 T

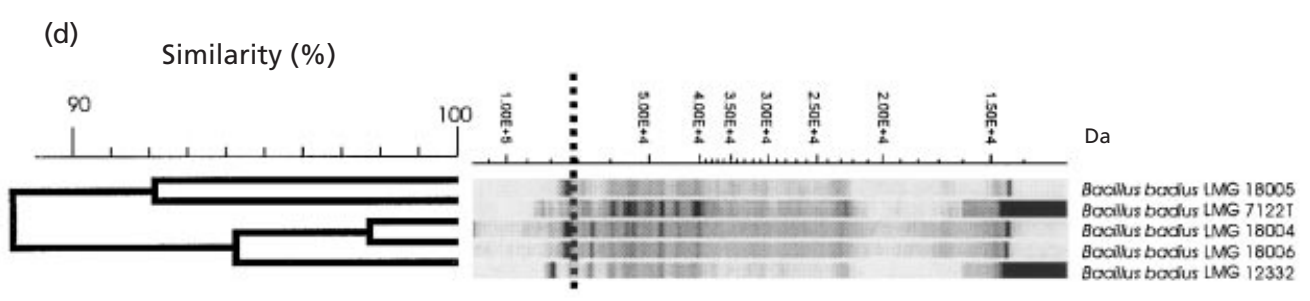

Fig. 3. (a) Clustering of SDS-PAGE analysis of Brevibacillus centrosporus strains also shown in Fig. 2, but using only the zone between points 52 and 330 and thus omitting the high molecular mass bands above $85 \mathrm{kDa}$ (all bands to the left of the dotted line) that are present in some, but not all strains of this species and which disturbed the clustering in Fig. 2. (b) Clustering of SDS-PAGE analysis of Brevibacillus choshinensis strains also shown in Fig. 2, but using only the zone between points 52 and 330 and thus omitting the high molecular mass bands above $85 \mathrm{kDa}$ (all bands to the left of the dotted line) that are present in some, but not all strains of this species and which disturbed the clustering in Fig. 2. (c) Clustering of SDS-PAGE analysis of Brevibacillus agri strains also shown in Fig. 2, but using only the zone between points 52 and 330 and thus omitting the high molecular mass bands above $85 \mathrm{kDa}$ (all bands to the left of the dotted line) that are present in some, but not all strains of this species and which disturbed the clustering in Fig. 2. (d) Clustering of SDSPAGE analysis of Bacillus badius strains also shown in Fig. 2, but using only the zone between points 70 and 330 and thus omitting the high molecular mass bands above $70 \mathrm{kDa}$ (all bands to the left of the dotted line) that are present in some, but not all strains of this species and which disturbed the clustering in Fig. 2. 


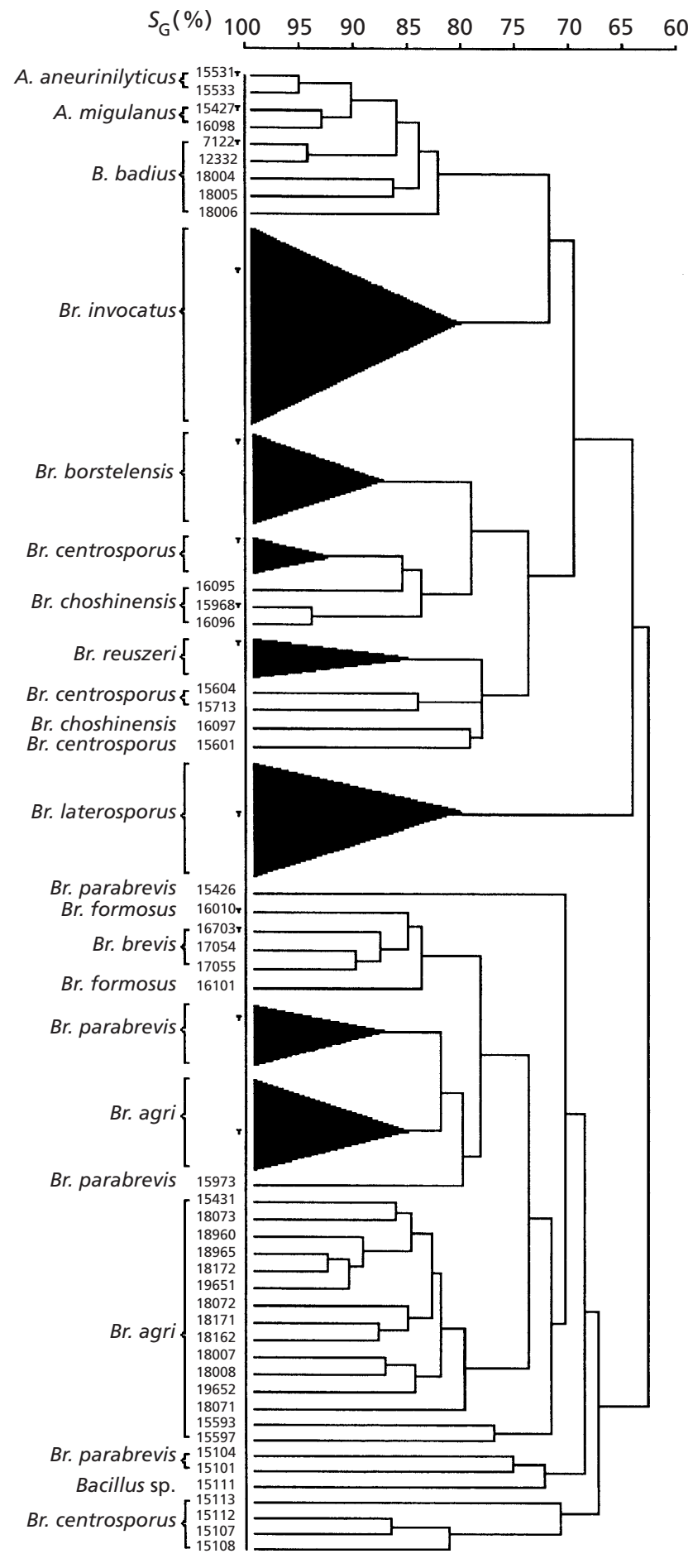

Fig. 4. Simplified phenogram based upon the UPGMA clustering of similarity coefficients $\left(S_{G}\right)$ of 115 phenotypic characters of 4 Aneurinibacillus strains, 5 Bacillus strains and 81 Brevibacillus strains. T indicates the position of the type strain.

ness (Nakamura, 1993; Takagi et al., 1993; Shida et al., 1995).

The three strains LMG 18071-18073, isolated in association with an outbreak of water-borne illness in
Sweden, showed $100 \%$ similarity in ARDRA (Fig. 1) and lay close $(91 \%)$ to the cluster containing Brevibacillus agri $\mathrm{LMG} 15103^{\mathrm{T}}$. Although the strains were inseparable by ARDRA, their profiles in PAGE and in API and other phenotypic tests showed some variation (Figs 2, 3 and 4), indicating that they did not represent three isolations of the same strain. In PAGE, strain LMG 18072 was recovered as an outlier of the main Brevibacillus agri group (Fig. 2), but this was largely owing to a poor profile with weak bands. For reasons unknown, some Brevibacillus strains (especially those belonging to Brevibacillus laterosporus, but occasionally representatives of other species too) showed many fuzzy protein bands in the SDS-PAGE analysis. In a few cases the PAGE pattern could be improved under more stringent conditions of the timing of harvesting the cells, lysis of the cells, etc. In all other cases we did not include the PAGE patterns in the numerical analysis. The generation of fuzzy protein banding has also been reported for other taxa (e.g. Doignon-Bourcier et al., 1999). In the API and other phenotypic test analyses (Fig. 4), strains LMG 1807118073 were recovered in a loose cluster which formed at $80 \% S_{\mathrm{G}}$ and which merged with clusters containing the type strains of Brevibacillus brevis, Brevibacillus agri, Brevibacillus formosus and Brevibacillus parabrevis at only $74 \% S_{\mathrm{G}}$. The cluster containing LMG 18071-18073 also included strains isolated from the antibiotic fermenter, gelatin, milk and clinical specimens (Fig. 4); all of these other strains were identified as Brevibacillus agri (see below). As DNA-DNA binding experiments showed LMG 18071 to have relatedness of $86 \cdot 3-92 \cdot 2 \%$ to Brevibacillus agri $\mathrm{LMG}$ $15103^{\mathrm{T}}$ in reciprocal experiments (Table 2), it can be concluded that the water-borne illness isolates are members of Brevibacillus agri. Although this is the first report of Brevibacillus agri being associated with illness, there have been occasional reports of 'Bacillus brevis' (the species from which Brevibacillus agri was derived) being implicated in corneal infection and food poisoning (Logan, 1988), and Brevibacillus agri strains LMG 15592 and 15593 were also clinical isolates (Table 1).

The 12 strains LMG 18161, 18164-18167, 18169, $18170,18959,18961-18963$ and 18966 were all isolated from the same antibiotic fermenter plant over a period of several months and they clustered as distinct groups in numerical analyses of ARDRA, PAGE, API and other phenotypic test data (Figs 1-4, where they are labelled as Brevibacillus invocatus). In ARDRA (Fig. 1), 10 of the strains clustered at $90.5 \%( \pm 2 \%)$ similarity, while strain LMG 18963 was an outlier joining at $87.5 \%$ similarity. Nine strains of this group clustered by $92.5 \%$ similarity in the PAGE analysis (Fig. 2), with LMG 18963 joining at $84 \%$ similarity. All 12 strains characterized by API and other phenotypic characters also clustered together; nine strains grouped at $91 \% S_{\mathrm{G}}$, with LMG 18961 and LMG 18966 joining at $86 \%$ and LMG 18963 joining at $80 \%$; thus, LMG 18963 was found to lie at the border 


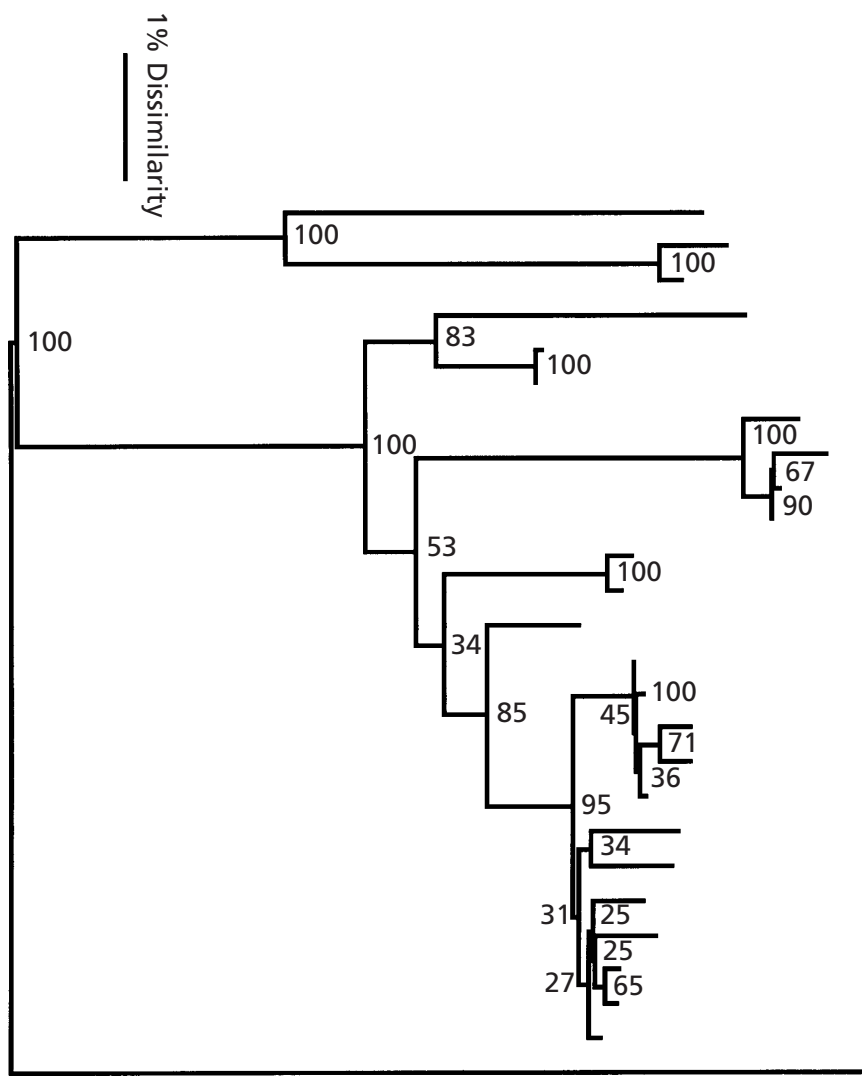

$\begin{array}{lll}\text { Aneurinibacillus thermoaerophilus } & \text { DSM 10154T } & \text { X94196 } \\ \text { Aneurinibacillus aneurinilyticus } & \text { DSM 5562T } & \text { X94194 } \\ \text { Aneurinibacillus migulanus } & \text { ATCC 9999T } & \text { D78462 } \\ \text { Brevibacillus thermoruber } & \text { DSM 7064T } & \text { Z26921 } \\ \text { Brevibacillus borstelensis } & \text { NRRL NRS-818T } & \text { D78456 } \\ \text { Brevibacillus borstelensis } & \text { LMG 15536 } & \text { AF378230 } \\ \text { Brevibacillus laterosporus } & \text { JCM 2496T } & \text { D78461 } \\ \text { Brevibacillus laterosporus } & \text { ATCC 64T } & \text { X57307 } \\ \text { Brevibacillus laterosporus } & \text { IAM 12465T } & \text { D16271 } \\ \text { Brevibacillus laterosporus } & \text { NCDO 1763T } & \text { X60620 } \\ \text { Brevibacillus invocatus } & \text { LMG 18167 } & \text { AF378231 } \\ \text { Brevibacillus invocatus } & \text { LMG 18962T } & \text { AF378232 } \\ \text { Brevibacillus centrosporus } & \text { NRRL NRS-664T } & \text { D78458 } \\ \text { Brevibacillus agri } & \text { M1-5 } & \text { AB039334 } \\ \text { Brevibacillus agri } & \text { MC-C1 } & \text { AB048253 } \\ \text { Brevibacillus agri } & \text { NRRL NRS-1219T } & \text { D78454 } \\ \text { Brevibacillus agri } & \text { NRRL NRS-1689 } & \text { U65892 } \\ \text { Brevibacillus agri } & \text { LMG 18172 } & \text { AF378233 } \\ \text { Brevibacillus parabrevis } & \text { IFO 12334T } & \text { D78463 } \\ \text { Brevibacillus reuszeri } & \text { NRRL NRS-1206T } & \text { D78464 } \\ \text { Brevibacillus choshinensis } & \text { HPD52T } & \text { D78459 } \\ \text { Brevibacillus brevis } & \text { JCM 2503T } & \text { D78457 } \\ \text { Brevibacillus formosus } & \text { NRRL NRS-863T } & \text { D78460 } \\ \text { Brevibacillus formosus } & \text { LMG 16101 } & \text { AF378234 } \\ \text { Brevibacillus brevis } & \text { NCIMB 9372T } & \text { X60612 } \\ \text { Paenibacillus polymyxa } & \text { NCDO 1774T } & \text { X60632 }\end{array}$

Fig. 5. 16S rDNA bootstrap analysis (500 calculations) of a neighbour-joining (Bionumerics software; Applied Maths) clustering of the type strains of Brevibacillus species and other relevant references. Unknown bases were discarded and the gapcost was $0 \%$. Possible variation of deposited sequences is demonstrated by the inclusion of repeated sequence determination for the type strain of Brevibacillus laterosporus. The figure also shows the low discrimination potential of this methodology for Brevibacillus parabrevis, Brevibacillus reuszeri, Brevibacillus formosus, Brevibacillus brevis and Brevibacillus choshinensis.

of the main group according to ARDRA, PAGE, API and other phenotypic characters. The results indicate that this group of antibiotic fermenter isolates could be distinguished from other Brevibacillus species using routine phenotypic tests. Strains 18167 and 18962 showed $70 \%$ DNA relatedness (mean value of reciprocal experiments; Table 2). In the $16 \mathrm{~S}$ rDNA sequence comparison tree (Fig. 5), these two strains were close to each other (above $99 \%$ similarity in $16 \mathrm{~S}$ rDNA sequence) and well separated (less than 97\% similarity in sequence) from their nearest relatives, Brevibacillus agri, Brevibacillus borstelensis, Brevibacillus centrosporus, Brevibacillus laterosporus and Brevibacillus thermoruber. We therefore propose this group of isolates as a new species of Brevibacillus, with the name Brevibacillus invocatus. A description of the organism is given below and Table 3 shows the discriminating characters at the species level.

Other strains isolated from the antibiotic fermenter plant and its product, during the same period as the isolations we have allocated to Brevibacillus invocatus, were also clearly members of the genus Brevibacillus. Strain LMG 18965 showed the same ARDRA pattern as two authentic strains of Brevibacillus brevis (Fig. 1) and it might have been provisionally identified as a strain of Brevibacillus brevis. However, the type strain of that species was recovered within the Brevibacillus agri part of the Brevibacillus brevis ARDRA complex (at above $92 \%$ similarity) and hence these two species cannot be separated by this technique. Indeed, PAGE analysis allocated LMG 18965 to the same cluster as the type strain of Brevibacillus agri. Four other antibiotic fermenter isolates, LMG 18162, 18171, 18172 and 18960 , showed $100 \%$ similarity in ARDRA and clustered with the two strains LMG 18007 and 18008 which were isolated from the gelatin processing plant (Fig. 1). The loose clustering $\left(82 \% S_{\mathrm{G}}\right)$ of these seven strains in API and other phenotypic test analyses (Fig. 4) is consistent with the main Brevibacillus agri cluster forming at only $81 \%$ similarity in PAGE analysis (see also Fig. 3c). Strains LMG 19651 and 19652, from 'commercially sterilized' milk, are also found in the Brevibacillus brevis ARDRA complex; they could not be separated from each other, nor from the above-mentioned seven strains, on the basis of their ARDRA patterns. In PAGE the two milk strains showed $97 \%$ similarity and lay within the Brevibacillus 


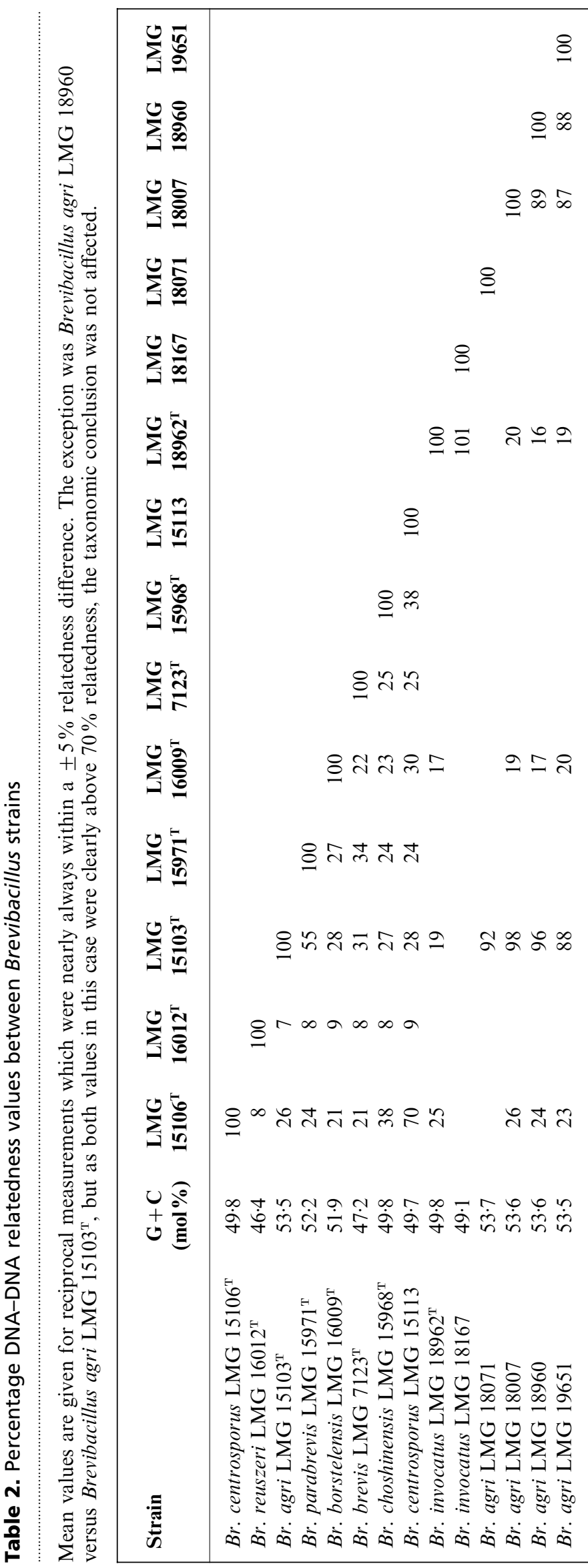

agri cluster. They also clustered with the five antibiotic fermenter strains and the two gelatin strains in the API and other phenotypic test analyses. The PAGE, API and other phenotypic test results of these nine strains thus support their identification as Brevibacillus agri and the rDNA sequence comparison placed strain LMG 18172 in a cluster with four other strains of this species (Fig. 5). Strain LMG 15431 was received as 'Bacillus brevis' in 1977, and our ARDRA, PAGE, API and other phenotypic test data all support the transfer of this strain to Brevibacillus agri.

Strain LMG 15111 lay at the periphery of the Brevibacillus brevis complex in ARDRA (Fig. 1) and in the phenotypic analysis (Fig. 4), while in PAGE it joined with the Brevibacillus parabrevis and Brevibacillus reuszeri clusters at low similarity. This Swedish industrial isolate is therefore regarded here as an unaffiliated member of Brevibacillus.

Three further isolates from the gelatin processing plant, LMG 18004, 18005 and 18006, clustered in ARDRA (Fig. 1) with the type and one other strain of Bacillus badius at above $92 \%$ similarity, and so can be regarded as members of this species. These isolates were also identified, according to their fatty acid pattern in the MIDI commercial system, as Bacillus badius at around $84.5 \%$ similarity. Furthermore, they also clustered with the Bacillus badius type strain in PAGE analysis (if particular zones containing heavy protein bands were omitted; Figs 2 and 3d) and in the analysis of API and other phenotypic test data (Fig. 4). In the latter analysis, Bacillus badius strains were not separable from Aneurinibacillus aneurinilyticus and Aneurinibacillus migulanus, a problem also observed by Heyndrickx et al. (1997). In previous PAGE interpretations (Heyndrickx et al., 1996a) it was shown that heavy protein bands in a particular zone can greatly disturb cluster analyses of PAGE patterns which appear very similar on visual examination. The polyphasic approach is clearly decisive and allocates the three gelatin isolates to Bacillus badius.

Turning to some further clinical isolates, three strains isolated from human blood specimens in Sweden, LMG 15107, 15108 and 15112, and strain LMG 15113 from a bronchio-alveolar lavage specimen, clustered together at $89 \%$ similarity in ARDRA (Fig. 1), within a cluster containing the type and other strains of Brevibacillus centrosporus. If the molecular mass zone above $85 \mathrm{kDa}$ was omitted from the numerical analysis of the PAGE patterns of LMG 15107, 15108, 15112 and 15113 , a grouping of at least $77 \%$ similarity was obtained (Fig. 3a; see also comment on the Bacillus badius PAGE data above). The Brevibacillus centrosporus reference strain LMG 15604, together with strain LMG 15113 were far removed from the reference strains of Brevibacillus centrosporus in the PAGE analysis (Fig. 3a). In the analysis of API and other phenotypic test data (Fig. 4) strains LMG 15107, 15108 and 15112 clustered together at $82 \% S_{\mathrm{G}}$, but LMG 15113 showed less than $72 \% S_{\mathrm{G}}$ to the others and none of them were recovered close to strains 
Table 3. Phenotypic characters for differentiating Brevibacillus invocatus from other Brevibacillus species, Aneurinibacillus species and Bacillus badius

$\mathrm{v}$, Between strain variation.

\begin{tabular}{|c|c|c|c|c|c|c|c|c|c|c|c|c|c|c|c|}
\hline Character* & $\begin{array}{c}\text { Br. } \\
\text { invocatus }\end{array}$ & $\begin{array}{c}B r . \\
\text { agri }\end{array}$ & $\begin{array}{c}\text { Br. } \\
\text { borstelensis }\end{array}$ & $\begin{array}{c}\text { Br. } \\
\text { brevis }\end{array}$ & $\begin{array}{c}\text { Br. } \\
\text { centrosporus }\end{array}$ & $\begin{array}{c}\text { Br. } \\
\text { choshinensis }\end{array}$ & $\begin{array}{c}\text { Br. } \\
\text { formosus }\end{array}$ & $\begin{array}{c}\text { Br. } \\
\text { laterosporus }\end{array}$ & $\begin{array}{c}\text { Br. } \\
\text { parabrevis }\end{array}$ & $\begin{array}{c}\text { Br. } \\
\text { reuszeri }\end{array}$ & $\begin{array}{c}B r . \\
\text { thermoruber }\end{array}$ & $\begin{array}{c}A . \\
\text { aneurinilyticus }\end{array}$ & $\begin{array}{c}\text { A. } \\
\text { migulanus }\end{array}$ & $\begin{array}{c}\text { A. } \\
\text { thermoaerophilus }\end{array}$ & $\begin{array}{c}\text { Bacillus } \\
\text { badius }\end{array}$ \\
\hline \multicolumn{16}{|l|}{ Hydrolysis of: } \\
\hline Casein & - & + & + & + & - & - & + & + & + & - & + & - & - & + & + \\
\hline Gelatin & - & + & + & + & - & - & + & + & + & - & + & - & - & + & + \\
\hline \multicolumn{16}{|l|}{ Growth at: } \\
\hline $55^{\circ} \mathrm{C}$ & - & - & - & - & - & - & - & - & - & - & + & - & - & + & - \\
\hline $20^{\circ} \mathrm{C}$ & + & $\mathrm{v}$ & - & - & + & + & + & $\mathrm{v}$ & + & + & - & - & + & - & + \\
\hline \multicolumn{16}{|l|}{ Assimilation of: } \\
\hline D-Alanine & - & $\mathrm{v}$ & + & + & - & - & + & - & + & - & - & + & + & + & + \\
\hline L-Alanine & $+\dagger$ & + & + & + & - & - & + & + & + & + & - & + & + & + & + \\
\hline L-Aspartate & - & + & - & + & + & + & + & + & + & + & - & + & + & + & + \\
\hline D-Fructose & - & + & + & + & - & - & + & + & - & $\mathrm{v}$ & - & - & + & $\mathrm{v}$ & - \\
\hline Fumarate & - & + & + & $\mathrm{v}$ & + & $\mathrm{v}$ & + & + & - & - & - & + & + & + & + \\
\hline D-Gluconate & - & + & + & + & + & - & + & - & + & + & - & $\mathrm{v}$ & - & - & - \\
\hline Glutamate & + & + & + & + & + & - & + & + & + & + & - & + & + & + & + \\
\hline DL-Glycerate & - & - & + & - & - & - & - & + & - & + & - & - & - & $\mathrm{v}$ & - \\
\hline Glycerol & - & + & + & + & - & - & + & + & + & - & - & + & + & + & + \\
\hline 2-Ketoglutarate & + & + & - & $\mathrm{v}$ & + & - & + & $\mathrm{v}$ & + & + & - & $+\dagger$ & $\mathrm{v}$ & + & + \\
\hline DL-Lactate & + & + & - & - & + & - & + & - & - & + & - & + & + & + & + \\
\hline Lactulose & - & - & - & - & - & - & - & - & - & + & - & - & - & - & - \\
\hline Maltose & - & + & - & + & - & - & + & + & + & - & - & - & - & - & - \\
\hline D-Mannitol & + & + & - & + & + & $\mathrm{v}$ & + & + & + & + & - & - & - & $\mathrm{v}$ & - \\
\hline N-Acetyl-D-glucosamine & - & + & - & + & + & + & + & + & + & + & - & $-\dagger$ & - & + & - \\
\hline Phenylacetate & + & + & + & + & - & - & + & - & + & + & - & $+\dagger$ & + & + & + \\
\hline Quinate & + & - & - & - & - & - & - & - & - & - & - & - & - & + & - \\
\hline Sucrose & - & + & - & + & - & - & + & - & + & - & - & - & - & - & - \\
\hline D-Trehalose & - & + & - & + & - & - & + & + & + & - & - & - & - & - & - \\
\hline D-Turanose & - & + & - & + & - & - & + & - & + & - & - & - & - & $\mathrm{v}$ & - \\
\hline
\end{tabular}

* With the exceptions of hydrolysis of casein and gelatin, and growth at 55 and $20^{\circ} \mathrm{C}$, all characters were determined using tests in the API Biotype 100 System.

$\dagger$ Reaction for $>85 \%$ strains tested. 
received as Brevibacillus centrosporus; they were outliers of the Brevibacillus brevis-Brevibacillus agriBrevibacillus formosus-Brevibacillus parabrevis group. However, in DNA-DNA binding experiments (Table 2) strain LMG 15113 showed $70 \%$ DNA relatedness (reciprocal values of 63 and $77 \%$ ) to the type strain of Brevibacillus centrosporus (LMG 15106 ${ }^{\mathrm{T}}$ ). Although this mean DNA relatedness value might be interpreted as the borderline for a new species, we regard the four clinical isolates as members of Brevibacillus centrosporus.

Two other Swedish clinical isolates, LMG 15101 and 15104, joined at $96 \%$ similarity in ARDRA and clustered with the type strain of Brevibacillus parabrevis, LMG 15971, at $87 \%$ (Fig. 1). Although this rather heterogeneous clustering based on rRNA suggests a taxonomic heterogeneity at the species level, the above three strains, together with LMG 15426, 15973, 16011,15428 and 16100, were well separated from the other Brevibacillus species in the ARDRA clustering. Furthermore, LMG 15101 clustered well above $80 \%$ similarity with the type strain of Brevibacillus parabrevis in ARDRA, and at $83 \%$ with this type strain in PAGE, although LMG 15104 lies closer to Brevibacillus agri in PAGE (Fig. 2). We therefore tentatively regard this group of isolates as members of Brevibacillus parabrevis. The heterogeneity of the group was also seen in the API and other phenotypic test data (Fig. 4). Indeed, some strains (LMG 15101 and 15104) were recovered as outliers of the phenotypically unresolved Brevibacillus brevis-Brevibacillus agriBrevibacillus formosus-Brevibacillus parabrevis group.

While members of the species Brevibacillus agri, Brevibacillus brevis, Brevibacillus centrosporus, Brevibacillus choshinensis and Brevibacillus formosus were not readily separated in ARDRA, the other members of this genus, Brevibacillus borstelensis, Brevibacillus laterosporus, Brevibacillus parabrevis and Brevibacillus reuszeri, were more easily distinguished by this technique (Fig. 1). The clusters of Brevibacillus borstelensis and Brevibacillus reuszeri, strains, however, lay close and merged at $89 \%$ similarity in ARDRA, with one Brevibacillus borstelensis strain (LMG 16103) being recovered as an outlier of this group. Strain LMG 15536 was received as a strain of 'Bacillus brevis' in 1977, but in PAGE it clustered with the type strain of Brevibacillus borstelensis at $90 \%$ similarity, and by API and other phenotypic tests, where Brevibacillus borstelensis, Brevibacillus laterosporus and Brevibacillus invocatus were convincingly separated from the other members of this genus (Fig. 4), LMG 15536 joined with the Brevibacillus borstelensis cluster at $95 \% S_{G}$. In ARDRA it was not recovered in any of the species clusters and, when taken with the data from the other methods, this suggests that the ARDRA pattern was disturbed, perhaps by an incomplete restriction digest. Moreover, in a FASTA search the $16 \mathrm{~S}$ rDNA sequence of LMG 15536 showed more than 99\% similarity with the type strain of Brevibacillus borstelensis.
Careful examination of the FAME data showed that this technique is of limited value for the discrimination of most Brevibacillus species (detailed FAME data are given in a table available in the online version of this paper at http://ijs.sgmjournals.org). However, the FAME data have some diagnostic value for a few species. We will consider here only the mean data for those species for which at least five strains have been investigated: Brevibacillus agri, Brevibacillus borstelensis, Brevibacillus laterosporus, Brevibacillus parabrevis, Brevibacillus choshinensis and Brevibacillus invocatus. For the last two species, the mean of the ratio anteiso-C15:0 versus iso-C15:0 was above 3.0 , while for the other four species it was, at most, 1.0. Furthermore, Brevibacillus borstelensis and Brevibacillus parabrevis could be discriminated from these other species by having much lower amounts of isoC14:0 (below 4\%). Finally Brevibacillus laterosporus showed less than $1 \%$ of $16: 1 \omega 7 c$ alcohol while all others had at least $2 \%$ or more of this component.

The difficulties that may attend the identification of these unreactive, aerobic endospore-forming bacteria in the routine laboratory are clear. Useful routine phenotypic characters are few (Table 3) and do not always give clear distinctions between the currently recognized species. Even when a polyphasic approach is taken, identifications are not always clear-cut, as we found with some of our clinical isolates. Aside from the new species Brevibacillus invocatus, which is phenotypically distinct, it may be questioned whether the current taxonomy of Brevibacillus best serves the needs of the diagnostic bacteriologist, and it might be argued that certain species might better be merged to give a more practically useful classification of this genus.

\section{Description of Brevibacillus invocatus sp. nov.}

Brevibacillus invocatus (in.vo.ca'tus; M.L. adj. invocatus, uninvited, referring to the isolation of strains of this organism as contaminants of an industrial fermentation).

Gram-negative, motile, rod-shaped cells, $0 \cdot 5-1 \cdot 0 \mu \mathrm{m}$ by $2 \cdot 0-6 \cdot 0 \mu \mathrm{m}$. Strictly aerobic. The ellipsoidal spores are borne subterminally, occasionally terminally, and swell the sporangia (Fig. 6). Grows on routine media such as nutrient agar and trypticase soy agar. Growth at $30^{\circ} \mathrm{C}$ is initially slow, with more rapid growth following $24 \mathrm{~h}$ incubation; after 3-4 days the slightly umbonate colonies are $1-8 \mathrm{~mm}$ in diameter, with slightly irregular margins. Colonies are brownishyellow, some with a single whitish concentric zone at the margin, and they are butyrous and have silky surfaces; the centres are opaque and the edges translucent. Catalase-positive. Nitrate reduction-negative. Casein, gelatin, starch and urea are not hydrolysed and indole is not produced. Growth temperatures range from 15 to $35^{\circ} \mathrm{C}$. Growth occurs between $\mathrm{pH} 6.0$ and 8.5. Few carbohydrates are assimilated and acid is produced weakly, if at all, from them; amino acids and some organic acids are used as carbon sources. The 


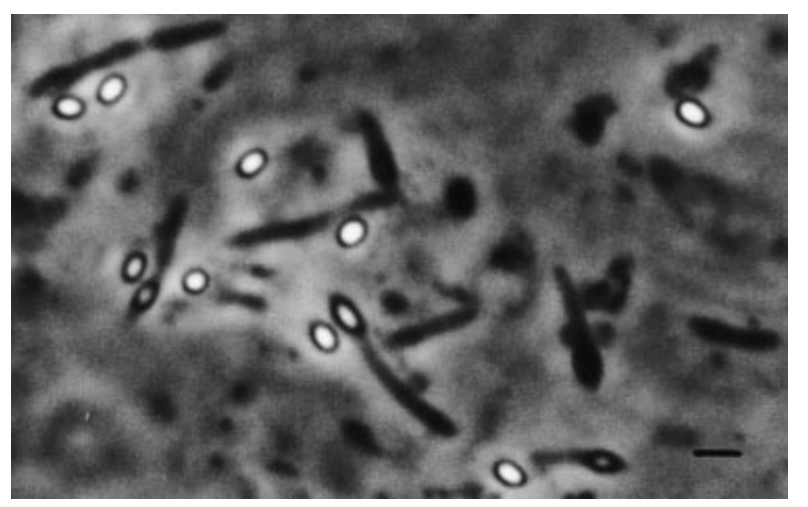

Fig. 6. Photomicrograph of sporangia and vegetative cells of the type strain of Brevibacillus invocatus viewed by phasecontrast microscopy; ellipsoidal spores lie subterminally in slightly swollen sporangia. Bar, $2 \mu \mathrm{m}$.

following carbon sources are assimilated in the API Biotype 100 System: L-glutamate, DL-3-hydroxybutyrate, 2-ketoglutarate, DL-lactate, D-mannitol, phenylacetate, L-proline, quinate, D-ribose and L-tyrosine and L-alanine. Propionate and L-serine are usually assimilated. Assimilation varies between strains for 2keto-D-gluconate, L-rhamnose and succinate. Aesculin hydrolysis varies between strains. The following carbon sources are occasionally assimilated: adonitol, 4aminobutyrate, L-aspartate, D-fructose, fumarate, Dgalacturonate, DL-glycerate, L-malate, malonate, palatinose, D-trehalose and D-xylose. The following substrates are not assimilated: $N$-acetyl-D-glucosamine, cis-and trans-aconitate, D-alanine, 5-aminovalerate, Larabinose, $\mathrm{D}$ - and L-arabitol, benzoate, betain, caprate, caprylate, D-cellobiose, citrate, $m$-coumarate, dulcitol, $i$-erythritol, ethanolamine, L-fucose, D-galactose, $\beta$-gentiobiose, gentisate, D-glucose, D-glucosamine, D-gluconate, D-glucuronate, glutarate, glycerol, histamine, L-histidine, 3-hydroxybenzoate, 4-hydroxybenzoate, hydroxyquinoline- $\beta$-glucuronide, myo-inositol, itaconate, 5-keto-D-gluconate, $\alpha$-lactose, lactulose, Dlyxose, D-mannose, D-melezitose, 1- $O$-methyl- $\alpha$-galactopyranoside, 1-O-methyl- $\beta$-galactopyranoside, 1-Omethyl- $\alpha$-D-glucopyranoside, $1-O$-methyl- $\beta$-D-glucopyranoside, 3- $O$-methyl-D-glucopyranose, D-malate, maltitol, maltose, maltotriose, D-melibiose, mucate, 3-phenylpropionate, protocatechuate, putrescine, Draffinose, D-saccharate, D-sorbitol, L-sorbose, sucrose, D-tagatose, D- and L-tartrate, meso-tartrate, tricarballylate, trigonelline, tryptamine, L-tryptophan, D-turanose and xylitol. The major cellular fatty acid components (accounting for more than $1 \%$ of the total fatty acid content) are, in descending order of content: anteiso-C15:0, iso-C15:0, iso-C14:0, $\mathrm{C} 16: 1 \omega 7 c$ alcohol, iso-C16:0 and iso-C17: $1 \omega 10 c$. The $\mathrm{G}+\mathrm{C}$ content ranges from $49 \cdot 7 \mathrm{~mol} \%$ for the type strain to $49 \cdot 1$ for LMG 18167. The type strain is LMG $18962^{\mathrm{T}}$ (= B2156 $6^{\mathrm{T}}=$ CIP $106911^{\mathrm{T}}=$ NCIMB $13772^{\mathrm{T}}$ ) and in the variable assimilation characters listed above it is positive for L-alanine, 2-keto-D-gluconate, propionate and L-serine, and negative for L-rhamnose, succinate and aesculin.

\section{ACKNOWLEDGEMENTS}

We are most grateful to bioMérieux (France) for the gift of API Biotype 100 strips and media, and for supporting G.F. It is a pleasure to express our gratitude to several industrial microbiologists who wish to remain anonymous, to L. K. Nakamura for providing cultures and to H. G. Trüper for advice on nomenclatural etymology. P.D.V. and M.H. are indebted to the National Fund for personal and research grants. N.A.L. and P.D.V. are most grateful to the British Council and the National Fund for Scientific Research (Belgium) for the award of an Academic Research Collaboration Programme travel grant. The research was also partly supported by the project grant G.O.A. (1997-2002) from the Ministerie van de Vlaamse Gemeenschap, Bestuur Wetenschappelijk Onderzoek (Belgium).

\section{REFERENCES}

Ash, C., Farrow, J. A. E., Wallbanks, S. \& Collins, M. D. (1991). Phylogenetic heterogeneity of the genus Bacillus revealed by comparative analysis of small-subunit-ribosomal RNA sequences. Lett Appl Microbiol 13, 202-206.

Claus, D. \& Berkeley, R. C. W. (1986). Genus Bacillus Cohn 1872. In Bergey's Manual of Systematic Bacteriology, vol. 2, pp. 1105-1139. Edited by P. H. A. Sneath, N. S. Mair, M. E. Sharpe \& J. G. Holt. Baltimore: Williams \& Wilkins.

De Ley, J., Cattoir, H. \& Reynaerts, A. (1970). The quantitative measurement of DNA hybridization from renaturation rates. Eur $J$ Biochem 12, 133-142.

Doignon-Bourcier, F., Abdoulaye, S., Willems, A., Torck, U., Dreyfus, B., Gillis, M. \& De Lajudie, P. (1999). Diversity of Bradyrhizobia from 27 tropical Leguminosae species native of Senegal. Syst Appl Microbiol 22, 647-661.

Ezaki, T., Hashimoto, Y. \& Yabuuchi, E. (1989). Fluorometric deoxyribonucleic acid-deoxyribonucleic acid hybridization in microdilution wells as an alternative to membrane filter hybridization in which radioisotopes are used to determine genetic relatedness among bacterial strains. Int J Syst Bacteriol 39, 224-229.

Farrow, J. A. E., Ash, C., Wallbanks, S. \& Collins, M. D. (1992). Phylogenetic analysis of the genera Planococcus, Marinococcus and Sporosarcina and their relationships to members of the genus Bacillus. FEMS Microbiol Lett 93, 167-172.

Farrow, J. A. E., Wallbanks, S. \& Collins, M. D. (1994). Phylogenetic inter relationships of round-spore-forming bacilli containing cell walls based on lysine and the non-spore-forming genera Caryophanon, Exiguobacterium, Kurthia, and Planococcus. Int J Syst Bacteriol 44, 74-82.

Heyndrickx, M., Vandemeulebroecke, K., Hoste, B., Janssen, P., Kersters, K., De Vos, P., Logan, N. A., Ali, A. \& Berkeley, R. C. W. (1996a). Reclassification of Paenibacillus (formerly Bacillus) pulvifaciens (Nakamura 1984) Ash et al. 1994, a later subjective synonym of Paenibacillus (formerly Bacillus) larvae (White 1906) Ash et al. 1994, as a subspecies of $P$. larvae, with emended description of $P$. larvae as $P$. larvae subsp. larvae and P. larvae subsp. pulvifaciens. Int J Syst Bacteriol 46, 270-279.

Heyndrickx, M., Vauterin, L., Vandamme, P., Kersters, K. \& De Vos, P. (1996b). Applicability of combined amplified 16S rDNA restriction analysis (ARDRA) patterns in bacterial phylogeny and taxonomy. J Microbiol Methods 26, 247-259.

Heyndrickx, M., Lebbe, L., Vancanneyt, M. \& 7 other authors (1997). A polyphasic reassessment of the genus Aneurinibacillus, reclassification of Bacillus thermoaerophilus (Meier-Stauffer et al. 1996) 
as Aneurinibacillus thermoaerophilus comb. nov., and emended descriptions of $A$. aneurinilyticus corrig., A. migulanus, and A. thermoaerophilus. Int J Syst Bacteriol 47, 808-817.

Heyndrickx, M., Lebbe, L., Kersters, K., De Vos, P., Forsyth, G. \& Logan, N. A. (1998). Virgibacillus: a new genus to accommodate Bacillus pantothenticus (Proom and Knight 1950). Emended description of Virgibacillus pantothenticus. Int J Syst Bacteriol 48, 99-106.

Logan, N. A. (1988). Bacillus species of medical and veterinary importance. J Med Microbiol 25, 157-165.

Logan, N. A., Lebbe, L., Hoste, B. \& 7 other authors (2000). Aerobic endospore-forming bacteria from geothermal environments in northern Victoria Land, Antarctica and Candlemas Island, South Sandwich archipelago, with the proposal of Bacillus fumarioli sp. nov. Int $J$ Syst Evol Microbiol 50, 1741-1753.

Mesbah, M., Premachandran, U. \& Whitman, W. B. (1989). Precise measurement of the $\mathrm{G}+\mathrm{C}$ content of deoxyribonucleic acid by highperformance liquid chromatography. Int J Syst Bacteriol 39, 159-167.

Nakamura, L. K. (1993). DNA relatedness of Bacillus brevis Migula 1900 strains and proposal of Bacillus agri sp. nov., nom. rev., and Bacillus centrosporus sp. nov., nom. rev. Int J Syst Bacteriol 41, 510-515.

Pot, B., Vandamme, P. \& Kersters, K. (1994). Analysis of electrophoretic whole organism protein fingerprints. In Chemical Methods in Prokaryotic Systematics, pp. 493-521. Edited by M. Goodfellow \& A. G. O'Donnell. Chichester: Wiley.
Shida, O., Takagi, H., Kadowaki, K., Yano, H., Abe, M., Udaka, S. \& Komagata, K. (1994a). Bacillus aneurinolyticus sp. nov., nom. rev. Int J Syst Bacteriol 44, 143-150.

Shida, O., Takagi, H., Kadowaki, K., Udaka, S. \& Komagata, K. (1994b). Bacillus galactophilus is a later subjective synonym of Bacillus agri. Int J Syst Bacteriol 44, 172-173.

Shida, O., Takagi, H., Kadowaki, K., Udaka, S., Nakamura, L. K. \& Komagata, K. (1995). Proposal of Bacillus reuszeri sp. nov., Bacillus formosus sp. nov., nom. rev., and Bacillus borstelensis sp. nov., nom. rev. Int J Syst Bacteriol 45, 93-100.

Shida, O., Takagi, H., Kadowaki, K. \& Komagata, K. (1996). Proposal for two new genera, Brevibacillus gen. nov. and Aneurinibacillus gen. nov. Int J Syst Bacteriol 46, 939-946.

Tagaki, H., Shida, O., Kadowaki, K., Komagata, K. \& Udaka, S. (1993). Characterization of Bacillus brevis with descriptions of Bacillus migulanus sp. nov., Bacillus choshinensis sp. nov., Bacillus parabrevis sp. nov., and Bacillus galactophilus sp. nov. Int J Syst Bacteriol 43, 221-231.

Vauterin, L. \& Vauterin, P. (1992). Computer aided objective comparison of electrophoretic patterns for grouping and identification of microorganisms. Eur Microbiol 1, 37-41.

Vauterin, L., Yang, P., Hoste, B., Vancanneyt, M., Civerolo, E. L., Swings, J. \& Kersters, K. (1991). Differentiation of Xanthomonas campestris pv. citri strains by sodium dodecyl sulfate-polyacrylamide gel electrophoresis of proteins, fatty acid analysis, and DNA-DNA hybridization. Int J Syst Bacteriol 41, 535-542. 